Ayokunle Olumuyiwa Omobowale ${ }^{1}$

University of Ibadan, Department of Sociology,

Olugbenga Samuel Falase ${ }^{2}$

Lead City University, Department of Sociology,

Olufikayo Kunle Oyelade ${ }^{3}$

University of Ibadan, Department of Sociology,

Mofeyisara Oluwatoyin Omobowale ${ }^{4}$

University of Ibadan, College of Medicine,

Institute of Child Health,

Ibadan (Nigeria)
316.728:[616.98:578.834(669)"2020"

Original scientific paper

Submitted 24/06/2020

Accepted 30/08/2020

doi: 10.5937/socpreg54-27155

\title{
THE COVID-19 PANDEMIC AND EVERYDAY LIFE: THE RELATIONS OF LOCKDOWN, SOCIAL DISTANCING, FACE MASKING, DISCREET SALUTATION AND HAND HYGIENE IN NIGERIA
}

Abstract: This paper provides a contextual discourse on the COVID-19 pandemic and the consequent reality of taken-for-granted nuances using the epistemology of everyday sociology. The COVID-19 pandemic has become a global disease that has virtually affected all facets of life. Nigerian government has moved swiftly to curb the pandemic through containment protocols of lockdown, social distancing, face masking, discreet salutation and hand hygiene. As social actors continue to interact amid the pandemic, they construct and reconstruct the world around them through the social interpretations and contextual meanings derived from these containment protocols. The taken-for-granted nuances and meanings embedded in these micro interpretations allow social actors to take interpretive actions based on the meanings attached to COVID-19 pandemic and the containment protocols.

Keywords: COVID-19, Everyday Sociology, Pandemic Containment Protocols, Pandemic Reality in Nigeria

\footnotetext{
1 ao.omobowale@gmail.com

2 flash4real@yahoo.co.uk

3 oyeladeok@yahoo.com

4 feyisarat@yahoo.com
} 


\section{Introduction}

The COVID-19 pandemic has unarguably emerged as a disease of global phenomenal impact in the $21^{\text {st }}$ Century. Countries and citizens are affected across continents and cultures; and the health systems of many countries are overwhelmed. The greatest concerns on the COVID-19, especially in its early stages, were its novelty among the strains of Corona viruses and its capacity to rapidly spread across territories and peoples (Wang, Horby, Hayden and Gao, 2020, Rothan and Byrareddy, 2020). Nobody is immune or totally protected from COVID-19, and in short, the whole of the 7 billion population of the planet earth is potentially exposed to the COVID-19 pandemic. This explains the reason for the containment protocols of lockdown, social distancing, face masking, discreet salutation and hand hygiene that have been adopted across countries, with a corresponding huge impact on everyday social relations and reality due to corresponding relational interpretations. ${ }^{5}$

Since the diagnosis of the index case in Nigeria in the last days of February 2020, COVID-19 cases in the country has rapidly increased with confirmed cases more than 11,000 by the first week of June 2020 (Nigeria Centre for Disease Control, 2020a) . $^{6}$ This represents an exponential increase within a space of three months. It is however important to note that those numbers are only confirmed cases. Nigeria has tested 69,801 people as at 3 June 2020 (see Nigeria Centre for Disease Control, 2020b). With a population of over 200 million, more than 80 million of whom live in poor conditions that make them vulnerable to contracting the novel corona virus, there is every possibility that COVID-19 cases are more than reported. Nigeria implemented lockdown, social distancing, face masking, discreet salutation and hand hygiene as pandemic containment protocols, shortly after the index case was announced and dozens of other cases were reported in Lagos and Abuja. It is important to note that, based on observations and media reports, compliance to these protocols has been varied from firm to loose across the length and breadth of Nigeria. For example, while Lagos, Ogun, Osun, Rivers and Kaduna states enforced strict lockdowns, most other states only implemented dusk-to-dawn curfews. The campaigns for social distancing, face masking, discreet salutation and hand hygiene have been intensified across the nation. Within this short period of Nigeria's fight against the COVID-19 pandemic, the containment protocols have emerged as new realities of everyday life. This research, therefore, utilizes the epistemology of everyday sociology, to examine the taken-for-granted everyday relational realities of lockdown and movement restrictions, social distancing, face masking, discreet salutation and hand hygiene in the fight against COVID-19 in Nigeria.

In the last 100 years, there have been cases of corona virus outbreaks. The Great Flu of 1918-1920 that happened just after World War 1 with over 50 million deaths, had the greatest impact among the major disease outbreaks reported in the 20th Century (Lima and Sobral, 2020). Between the years 2002 and 2014, there were reported cases of the

5 Discreet salutation as used here, refers to the new methods of greetings with an inherent intention to limit body contact (especially hand shaking and hugging) to the barest minimum.

6 COVID-19 cases continue to increase rapidly in Nigeria reaching 18,480 on 18 June 2020. There is a livelihood of further rapid increases as many states open up as planned. 
Avian Flu (H5N1), Severe Acute Respiratory Syndrome (SARS) and Middle East Respiratory Syndrome (MERS) (Otter, Donskey, Yezli, et al 2016). The H5N1, SARS and MERS were quickly contained before they reached pandemic proportions. There were reported cases of $\mathrm{H} 5 \mathrm{~N} 1$ in poultry in Nigeria, but no human cases were confirmed (Oluwayelu, Meseko, Ayinmode et al 2020). The SARS and MERS were not reported in Nigeria. However, Ebola, another highly contagious disease was reported in Nigeria in July 2014. There were a total of 20 cases and 8 deaths due to Ebola in Nigeria (Ogoina, 2016). Prior to its entry into Nigeria, Ebola had ravaged the West African states of Sierra Leone, Liberia and Guinea leading to more than 11 thousand deaths. The report of the index case of Ebola in Nigeria effected the immediate new consciousness for temperature checking in public places, a check on hand shaking and enhanced hand hygiene among Nigerians (Ogoina 2016). Whereas, schools were shut, there were no movement restrictions or lockdowns. It is important to note, that the Ebola epidemic somewhat enhanced an initial consciousness of pandemic reality in the 21st Century among Nigerians. The containment protocols adopted for Ebola quickly fizzled out after Nigeria was declared free of the disease. The emergent relations due to COVID-19 have reignited the consciousness and relational practice of pandemic containment measures once again.

The Infectious Diseases Centre, Lagos (IDC-Lagos) played a major role in the treatment of Ebola cases and its containment. The same IDC-Lagos, received the first sets of COVID-19 cases in Nigeria. The IDC-Lagos is the model centre for COVID-19 management in Nigeria and has played a leading role in the containment of the pandemic. Unlike the Ebola outbreak, COVID-19 has had a greater impact. The social consciousness of COVID-19 and its recommended containment protocols are increasingly embedded in the social fabric and taken-for-granted everyday social relations and reality in Nigeria. This is not to say that the protocols have been strictly followed. However, the impacts of the COVID-19 protocols are ingrained in everyday actions and strategies as Nigerians respond to the realities of the COVID-19 Pandemic. This paper has 6 major sections. The first section provides the introduction. The second section discusses the epistemology of everyday sociology in the explanation of pandemic reality while the third section presents the methodology. The fourth section presents observational reflections on the COVID-19 containment protocols implemented in Nigeria, the fifth section discusses the findings and the sixth section provides the conclusion.

\section{Everyday Sociology in a Pandemic Reality}

The COVID-19 pandemic has once again affirmed the position that actors construct and reconstruct their social beings through the meanings they construct out of social interactions and reality (Harvey 2016, Ciocănel, Lazăr, Munch, et al, 2018). Human beings have experienced bouts of the corona virus strikes from time immemorial. Interpretations attached to the different strains of the corona virus have differed from mild to severe based on the disease epidemic-- pandemic and actors' lived experiences. The interpretations adduced to the Great Flu of 1918-1920, H5N1, SARS, MERS and lately COVID-19 tend more towards the meanings of dangerously severe contagious disease, capable of causing mass morbidity and mortality rapidly. Unlike the Great Flu, which caused massive deaths globally, scientists and medical actors were able to contain the spread of H5N1, SARS and 
MERS before they could reach pandemic spreads among human populations. Hence, for many actors, the trio of H5N1, SARS and MERS were mere potential threats with limited harm thus far. Many other interacting actors outside the research and biomedical communities have little or no knowledge of these strains of the corona virus and they make limited meaning to their realities.

The COVID-19 pandemic has reached a stage of global consciousness akin to the Great Flu of 1918-1920, though not yet, at the same degree of morbidity and mortality rates. Information and Communication Technology, and news and social media have no doubt aided the quick spread of the information about COVID-19, even in poor countries, with a direct effect on people's interpretations. ${ }^{7}$ The scientific and medical communities have presented COVID-19 as novel and with no known cure medications and vaccines (Wang, Horby, Hayden and Gao, 2020, Rothan and Byrareddy, 2020). The global health community as well as the mass and social media continuously reels out global morbidity and mortality rates due to COVID-19, while national governments too have implemented containment protocols, which citizens; as interacting social actors, continually interpret and act on based on the interpretations they construct out of the protocols. Social actors construct their pandemic realities out of the interpretations they make of and from COVID-19 statistics, protocols provided by national governments, international organisations (the World Health Organization, particularly), as well as news and social media. Governments, international organisations, news media and social media, thus, form the nodes of communications from where actors extract, exchange and relationally interpret COVID-19 information. The information extracted and shared, does not itself inform actions; rather, the interpretations constructed out of the information by interacting actors inform the courses of action. Hence, the social dimension of COVID-19 goes beyond scientific and medical statistics, analyses and news put out for dissemination. Rather, the social interpretations constructed by interacting actors inform the contextual shape of the COVID-19 pandemic reality.

Social interpretations and embedded relational actions of the COVID-19 pandemic are still evolving. There is, however, a global consciousness that the pandemic is a major cause of morbidity and mortality. Available information also shows that the pandemic has a capability to quickly overwhelm the health sector, health care providers, equipment and medications as cases rise above the bearable levels (Chatterjee, Chatterjee, Kumar and Shankar, 2020, Emanuel, Persad, Upshur, Thome, et al, 2020). It is for these reasons that the containment measures of lockdown, social distancing, face masking, discreet salutation and hand hygiene are recommended; implemented and enforced in many nations. These protocols have been implemented by macro structures at global and national governmental levels. Social actors also interpret and respond to the COVID-19 and the containment protocols at the micro levels based on existing interactions with the social and physical environments. This research is, thus, guided by the epistemology of everyday sociology, to particularly, explain the taken-for-granted nuances with embedded meanings to the interpretive understanding of COVID-19pandemic reality in Nigeria.

\footnotetext{
7 Many Nigerians have access to the ICT and Social Media due to the availability of relatively cheap
} imported secondhand and China-made electronics (Omobowale 2013a , 2013b, 2012) 


\section{Methodology}

The research adopted a reflexive design to collect and interpret observational and secondary data. The data for this study were gathered through online media sources and everyday observations on COVID-19 containment protocols of lockdown, social distancing, face masking, discreet salutation and hand hygiene in Nigeria. The research secured data from available media sources (including BBC, Aljazeera, Punch Newspaper, Guardian Newspaper, Business Day, Nigerian Tribune, Vanguard Newspaper and Radio Nigeria Ibadan) and observed seemingly innocuous interactions in public environments between March and May 2020without engaging in direct physical contacts with human actors because of the ethics guiding research during pandemic periods (Magnani and Magnani, 2020, Chaudhuri, 2020, Van Bavel, Baicker, Boggio et al, 2020). The observations were done in Ibadan city since COVID-19 containment protocols curtailed inter-city and inter-state travels.

\section{The COVID-19 Containment Protocols and Everyday Relations}

\section{a) Lockdown}

The Federal Government of Nigeria locked-down Lagos and Ogun states, and the Federal Capital Territory, Abuja on 30 March, 2020 as an early strategy to contain the community transmission of the novel corona virus ${ }^{89}$. Many other states also put in place some forms of movement restrictions, curfews, closure of schools, markets, shops and offices and ban on social and religious gatherings of more than 10-20 people. The guiding philosophy was that: 'viruses do not move, people move viruses'! The lockdown policy was meant to slow down the spread of the COVID-19 pandemic. The three territories initially lockeddown were the epicentres of the COVID-19 cases in Nigeria. There were only 131 confirmed COVID cases in Nigeria as at the time of the first announcement of the lockdown on 30 March (see Nigeria Centre for Disease Control, 2020b). Between 30 March and the first week of June, there has been over $8200 \%$ increase in confirmed cases to more than 11000 . Hypothetically, one could assume that there could have been more if the lockdown was not put in place. However, the mass population do not relate with hypothesis. They relate with emergent, existing and reoccurring situations to construct realities. A major reality constructed out is that the lockdown hurt livelihood and survival. People openly stated that the 'hunger virus occasioned by the lockdown was more deadly than the corona virus'. As the lockdown and curfew negatively impacted economic activities, many people who worked and earned daily income through the informal sector, especially, saw their livelihood adversely affected. Unable to access palliatives, they interpreted the lockdown as punishment and a hunger process that could lead to death (Osinusi, 2020). Coupled with the loss of income, crime rates momentarily increased especially in vulnerable environments

8 There were 81, 25 and 3 cases in Lagos, Abuja and Ogun respectively as at 30 March 2020 when the territories were locked-down. The numbers increased to 5663 (Lagos), 862 (Abuja) and 329 (Ogun) by 6 June 2020 (Nigeria Centre for Disease Control, 2020c).

9 The Federal government also locked down Kano state on 27 April after COVID-19 cases suddenly rose to over 70.COVID-19 cases in Kano have increased to 985 as at 6 June 2020 (Nigeria Centre for Disease Control, 2020c). 
(see for example Mbah, 14 April 2020, Lambo, 14 April 2020). Hence, the lockdown was interpreted as a measure that denied the vulnerable class income that was dearly needed for survival, and yet exposed them to insecurity. Lockdown became an unpopular measure enforced by the government; yet, welfare and security were adversely affected. The mass public did not interpret the lockdown and movement restriction as COVID-19 containment measures, but as the 'poor hurting measures' because livelihoods were badly affected and government palliatives were non-available for most of the mass public whose livelihoods were affected by the lockdown.

\section{b) Social Distancing}

Social or physical distancing is one of the important preventive measures prescribed and required for containment of COVID-19 globally (Abel and McQueen, 2020). In Nigeria, emphasis on social distancing is considered important, as the government both the Federal and State levels had banned social and religious gatherings that could encourage close contact among people. Some who attempted to have large gatherings and/or parties were strongly condemned and offenders were arrested. All schools, churches, mosques and events centres were closed, and inter-state movements were restricted. These steps were further strengthened by the Nigerian Centre for Disease Control (NCDC) standard operating procedures issued out to organisations on social distancing. Observably, many organisations like banks marked out three metres range intervals to ensure social distancing at the banking halls and Automated Teller Machine (ATM) points. While social distancing seems to have been achieved in some corporate settings, the market spaces and the public transport systems do not follow social distancing protocols (Radio Nigeria Ibadan, 2020).

Pre-existing nature of social and cultural relations is such that allows for close physical interactions both in economic and social space structures. For instance, the market space serves as the melting pot of many phenomena, such as whispering of price into ears, sharing of food and drinks, holding of physical economic association meetings in close spaces, hugging and shaking of hands to symbolise friendship and price deals. Ibadan market space accommodates the bulk of informal workers and provides essential food items and other resources to the public. The market spaces are usually densely populated with little or no space for movement without close contacts (Agusi, Ijoma, Nnochin, NjokuAchu et al, 2020, Radio Nigeria Ibadan, 2020, Omobowale, 2019). This is exemplified in Bodija market, the largest foodstuff market in South-Western Nigeria covering 56.9 hectares and attracting traders and buyers from all over Nigeria and a few countries in the West African coast (Omobowale 2019, Omobowale and Omobowale 2019). Bodija market like other big markets in the Nation, is a critical centre of livelihood and social survival for the people of Ibadan and environs. The market by social ecology and arrangement is densely populated, crowdie and rowdy, such that social distancing is very difficult to achieve in spite of the present reality of COVID-19. It is difficult to have an exact number of traders in Bodija market. However, it is safe to give an estimate of about 5,000 traders and about 15,000-20,000 buyers visit the market every day. The daily human traffic into Bodija market remains huge irrespective of the COVID-19 pandemic. Observably, there is no social distancing practice in place in the market. The market is characterised by people, loads and vehicles/lorries struggling for space and no one observed social distancing, 
not even a bit, because there was no space for it. Some traders and buyers wore face masks and in their consciousness this refers to social distancing as caution not to be deliberately touched by people. To many traders, social distancing is not possible because social closeness is embedded in day-to-day existence and transactions in the market. In short, social closeness is the heart of the market. Likewise, the pattern of the transport system in Nigeria allows for close contact, despite the physical distance regulations, many vehicles, tricycles and motorcycles still find it difficult to comply.

\section{c) Face Masking}

The use of facemask is one of the safety measures recommended by the health experts amid COVID-19 pandemic (Feng, Shen, Xia, et al, 2020, Liu and Zhang, 2020). The facemask is meant to protect individuals from spreading and/or contracting the virus through droplets that come out from people during conversations, coughs and sneezes. Initially, the World Health Organisation (WHO) recommended that facemask could be worn only by healthcare workers and sick people, but recently, as the virus continues to grow exponentially, the WHO recommended the need for all people to wear facemasks in public places (BBC News, 2020). However, while the biomedical and clinical purposes of using facemasks are being emphasised, this research observed a taken-for-granted socio-economic dimension to the use of facemasks. It was observed that the production of facemasks has become a source of income for many local tailors and other skilled and semi-skilled people to make some income (see for example Odoh, 2020). These tailors and traders produce facemasks made of local fabrics in large quantity. These fabric masks come as alternatives to medical masks that medical practitioners and surgeon wear in hospital, and are made readily available for people who cannot afford or access medical masks. The fabric face masks are hawked and traded along roadsides and at the entrance of public buildings that refuse entry to people who do not wear masks. Each facemask sells for as little as 100 150 (\$0.27-0.41). The WHO (2020) described the standardised form of fabric masks that must be used as alternatives to medical masks. These fabric masks must contain three layers - the outer, inner and mid layers. The outer layer should be made up of water resistant fabric; the inner layer has to be water absorbent fabric and the mid layer must contain a filter. Most of the improvised face masks sold on the street do not follow the WHO recommended standard. The researchers bought a few as samples. The samples have only one layer of fabric. The facemasks may thus not provide the protection intended. Such substandard facemasks only provide a symbolic sense of protection for the users, give the users and enforcement agents, a notion of facemask compliance, and provide income for street facemask makers and traders.

\section{d) Discreet Salutation}

Salutation is used in everyday interactions through communications to maintain interpersonal relationships (Wei, 2010). Since the outbreak of COVID-19, the mode of greetings has changed, to discreet salutation as much as practicable. The WHO advised against shaking of hands and hugs, which are considered as means through which coronavirus spread. The Nigerian social system is such that relations are tied around informal salutations. Hence, symbolic and innovative ways have been constructed for salutation. 
Aside the popularly recommended elbow and feet salutation, symbolic salutary expressions have been created out of the COVID-19 pandemic reality (Ekpu, 2020). Some of such salutations in Yoruba include: 'Aku asiko koro yi o' (greetings in this coronavirus period?), "Bawo ni koro yi lodo yin" (How is this coronavirus in your area?), 'Bawo le se n cope ninu koro yi' (How do you cope in this coronavirus period?). These various forms of corona virus induced salutations have been used to express peoples' feelings, concerns, interpretations and relational reality during the COVID-19 pandemic, which has resulted in livelihood difficulties among many people. For instance, 'how do you cope with coro?' is a form of a greeting-question that examines the coping strategy of people in this hardship period. Furthermore, prayers on coronavirus (coro prayers) have been used frequently as a form of salutation in interactional processes amid COVID-19 pandemic. These prayers are used to remind people of their faith and beliefs amid COVID-19 pandemic and have become everyday salutations as people relate together in their daily activities. Prayers frequently used are 'Lagbara Olorun, eje wa’o koro fun koro' (By God's grace, our blood will be bitter for the coronavirus), 'koro o ni rapala wo ile/ede wa o' (Coronavirus will not crawl into our houses/households), and 'A o ni r'ogun coro l'oruko Jesu' (We will not experience coronavirus in Jesus' name).Through these prayers, people create and recreate their meanings and understandings about the coronavirus, as it is interpreted as a demon or spirit (emi koro) that can only be defeated by warfare prayers (see Omobowale and Oyelade, 2017, Oyelade and Omobowale, 2015).

\section{e) Hand Hygiene}

Hand hygiene among others has been globally recommended as a vital strategy at containing person-to-person transmission of COVID-19. This includes frequent thorough hand washing with soap and running water, and the use of alcohol-based hand sanitizer (see Cavanagh, and Wambier, 2020). Extant reports indicate that about 150 million Nigerians lack access to handwashing facilities (Ewepu, 2020). However, we observed that in many ways, lives of the people in Nigeria have been influenced to have handwashing facilities especially in public places. At home, work places, worship centres, malls, and market places, it has become a common practice to put in place soap and water, usually at the entrance for people to wash their hands as frequent as possible. This has brought about industries, resourcefulness and innovations of various kinds. Notable among others, is the small-scale business of converting buckets and water kegs to hand washing facilities that are reasonably comfortable for public use. There is also the local production and sales of liquid soap by many individuals, although in an unregulated manner. Apart from the production and sales of such items, some individuals have devised special means of livelihood from provision of hand washing facilities, especially soap and water in key locations at public places, and they have patronage from the public. The increased need for regular hand hygiene has resulted in between $100 \%$ and $1000 \%$ increase in the prices of branded liquid soaps and hand sanitisers (see Onwuzoo, 2020). Hence, there is an increase in the production and sale of unregulated hand sanitisers and soap. This has enhanced the livelihood of sellers, and somewhat made soap and sanitisers affordable, yet, it has not erased the dangers associated with using adulterated and substandard soaps and sanitisers. Also, there are various speculations especially on home remedies and personal protective measures. 
One among others is that the local gin (ogogoro, also known as apeteshi) can be used in the absence of hand sanitizers. In fact, some have claimed that drinking the local gin will prevent and/or cure COVID-19 infection. The use of local gin is, thus used for the production of alcohol-based hand sanitizer, and some people have cultivated the habit of using it to wash their hands, and even drinking it with the belief that it kills the coronavirus (see Onwuzoo, 2020). In Nigeria, as it is globally, hand hygiene has become a practice either for the fear of, or as personal protection from COVID-19 infection (see Singhal, 2020). Some wash their hands from to time to time; and some go about with hand sanitizers in their pockets so that they use it as often as they remember to do so. In many restricted public places like banks, malls, among others, customers' attention is called to washing of hands by designated officials, before allowing them to gain entrance for whatever transaction. Hence, the interpretations imputed to the COVID-19 has evolved hand hygiene as an everyday practice, bringing along with it, the spread of unregulated local production and sale of liquid soap and hand sanitisers despite the associated health hazards.

\section{Further Discussion of Findings}

Beyond the biomedical and clinical dimensions of COVID-19 pandemic in Nigeria, the results presented denote a clear-cut subjective understanding of the taken-for-granted socially constructed contexts and nuances embedded in the everyday COVID-19 interpretations as people relate with one another in this difficult period. Thus, it speaks volumes of how social actors construct and reconstruct their entire world as national governments and corporate bodies and organisations advise local and global COVID-19 prevention measures. The social interpretations of COVID-19 protocols including lockdown, social distancing, face masking, discreet salutation and hand hygiene, are emanating from people's daily interaction and through such interpretations, contextual meanings on what these protocols mean, are conveyed.

Undoubtedly, the reality of COVID-19 pandemic and the containment protocols is best understood from the social interpretation and meanings of social actors. Being the targeted audience, such subjective interpretations and meanings, are crucial in understanding the reality of COVID-19 in their own way and in relation to others, which is germane to individual and societal development (Olutayo, 2014). As lockdowns continue across the country, businesses and survival strategies dwindle and the suffering became unbearable, especially for informal workers who survive on daily earnings. Thus, the lockdown policy was not interpreted as one implemented to curb COVID-19, but to expand the 'hunger virus' over the mass poor. What this infers is that, for most people, the lockdown as a containment of COVID-19 is meant to exploit the poor and to further draw them below the poverty line. Hence, successful implementation of and conformity to the lockdown policy is hinged on the contextual meanings and social interpretations of social actors.

Embedded in containment protocols of social distancing and discreet salutation, are also everyday actors' feelings, perceptions and meanings constructed as they interact in the pandemic (Adler, Adler and Fontana, 1987). While social distancing ensures physical distance from two people as they relate together in this pandemic, the social interpretations of social distancing convey more than the ordinary meaning of it, particularly, in market relations. The market is an interactional social space that social actors contest in to 
make daily living, hence, the possibility of social distancing, is virtually impossible. Social space, in this context, is shaped by human relations and bound by social and cultural rules of embeddedness (see Omobowale, 2019; Omobowale and Omobowale, 2019; Adebayo, Falase and Akintunde, 2017; Zieleniec, 2007). Also, discreet salutation as a form of everyday greetings has evolved as a dimension of an emotional strategy to constructively and interpretively cope with the social realities of the COVID-19 pandemic. The 'corona' interpretive context has become a domain through which societal members express their feelings, emotions, prayers, perspectives and interpretations on COVID-19 pandemic. Face masking and hand hygiene have also influenced the everyday interactions and reality. The compulsion of the use of facemasks and hand hygiene by the government has created the livelihood opportunities for local producers, yet, this new sector is unregulated and thus standards are not assured.

\section{Conclusion}

Nigeria entered the COVID-19 pandemic in February 2020. Despite the efforts put at some degree of preparedness, COVID-19 cases have rapidly increased to over 18000 by the third week of June. A primary focus is placed on measures at containing the spread of the corona virus. However, the containment measures of lockdown, social distancing, face making, hand hygiene and discreet salutation have evolved interpretive actions with which interacting actors continue to construct their lives in the pandemic period. Lockdown and social distancing are interpreted as difficult measures that worsen survival, and so are largely disregarded while face masking and hand hygiene have produced new economies of livelihood and survival for many skilled and semi-skilled mass public that produce largely non-standardised face masks and hand hygiene wares to earn some income. Whereas people avoid hand shaking and hugging as much as practicable, they however continually evolve meaningful salutations with embedded meanings of hope to remain free of the COVID-19 infection. It is difficult to affirm whether COVID-19 containment measures have been effective; however, actors interpretations of the measures have created contextual response realities among actors. 
Ајокунле Олумујива Омобовале ${ }^{1}$

Универзитет у Ибадану, Департман за социологију,

Олугбенга Самјуел Фаласе ${ }^{2}$

Градски универзитет Лид, Департман за социологију,

Олуфикајо Кунле Ојеладе ${ }^{3}$

Универзитет у Ибадану, Департман за социологију,

Мофејисара Олуватојин Омобовале

Универзитет у Ибадану, Медицински факултет,

Институт за здравље детета,

Ибадан (Нигерија)

\section{ПАНДЕМИЈА COVID-19 И СВАКОДНЕВНИ ЖИВОТ: ПОВЕЗАНОСТ ИЗОЛАЦИЈЕ, СОЦИЈАЛНОГ ДИСТАНЦИРАҢА, НОШЕЊА МАСКЕ, УЗДРЖАНОГ ПОЗДРАВЉАЪА И ОДРЖАВАҢА ХИГИЈЕНЕ РУКУ У НИГЕРИЈИ}

(Превоg In Extenso)

Сажетак: Овај рад даје контекстуални дискурс о пандемији COVID-19 и последично насталој реалности подразумеваних нијанси у примени епистемологије у социологији свакодневног живота. Пандемија COVID-19 постала је глобална болест која је утицала на дословно све аспекте живота. Влада Нигерије је брзо реаговала како би зауставила пандемију путем протокола у виду изолације, социјалног дистанцирања, ношења маске, уздржаног поздрављања и одржавања хигијене руку. С обзиром на то да се интеракције друштвених актера настављају и током пандемије, они граде и обнављају свет око себе кроз друштвена тумачења и контекстуална значења потекла из ових протокола за заустављање пандемије. Подразумеване нијансе и значења уграђена у та микро-тумачења омогућавају друштвеним актерима да предузму интерпретативне радње на основу значења приписаних пандемији COVID-19 и протоколима за њено заустављање.

Кључне речи: COVID-19, социологија свакодневног живота, протоколи за заустављање пандемије, пандемија као реалност у Нигерији

\footnotetext{
1 ao.omobowale@gmail.com

2 flash4real@yahoo.co.uk

3 oyeladeok@yahoo.com

4 feyisarat@yahoo.com
} 


\section{Увод}

Пандемија COVID-19 дефинитивно представља болест са глобалним утицајем на све појаве у 21. веку. Погођени су државе и грађани на свим континентима и у свим културама; преоптерећени су здравствени системи бројних земаља. Највећи разлози за забринутост у вези са вирусом COVID-19, поготово у раним фазама, били су то што је реч о новом соју коронавируса, као и то што може да се шири великом брзином на свим територијама и у разним народима (Wang, Horby, Hayden \& Gao, 2020 , Rothan \& Byrareddy, 2020). Нико није имун нити потпуно заштићен од вируса COVID-19 и, укратко, целокупно светско становништво које броји 7 милијарди потенцијално је изложено пандемији COVID-19. Ово објашњава разлог због којег су у разним земљама уведени протоколи за заустављање пандемије, односно изолација, социјално дистанцирање, ношење маске, уздржано поздрављање и одржавање хигијене руку, са огромним пратећим утицајем на свакодневне друштвене односе и реалност услед датих релационих тумачења. ${ }^{5}$

Од дијагностиковања нултог случаја у Нигерији на самом крају фебруара 2020. године, број заражених вирусом COVID-19 се у земљи нагло повећавао, те је у првој седмици јуна 2020. забележено више од 11.000 потврђених случајева (Nigeria Centre for Disease Control, 2020a) ${ }^{6}$. То представља експоненцијални раст у периоду од три месеца. Међутим, важно је напоменути да се ове цифре односе само на потврђене случајеве. У Нигерији је до 3. јуна 2020. године тестиран 69.801 човек (видети Nigeria Centre for Disease Control, 2020b). Имајући у виду да је укупан број становника преко 200 милиона, те да више од 80 милиона живи у сиромаштву које их чини осетљивима на нови коронавирус, постоји велика вероватноћа да заправо има много више случајева заразе COVID-19 него што је пријављено. Нигерија је увела изолацију, социјално дистанцирање, ношење маски, уздржано поздрављање и одржавање хигијене руку као протоколе за заустављање пандемије убрзо након откривања нултог случаја, односно када су десетине случајева биле пријављене у Лагосу и Абуџи. Важно је напоменути да, на основу запажања и медијских извештаја, поштовање ових протокола широм Нигерије варира од строгог до необавезног. На пример, док су државе Лагос, Огун, Осун, Риверс и Кадуна увеле строгу изолацију, остале државе већином су увеле само полицијски час од вечери до раног јутра. У читавој земљи интензивиране су кампање усмерене на социјално дистанцирање, ношење маске, уздржано поздрављање и одржавање хигијене руку. У овом кратком периоду током којег се Нигерија борила против пандемије COVID-19, протоколи заустављања заразе појавили су се као нове реалности у свакодневном животу. Стога ово истраживање користи епистемологију социологије свакодневног живота да би се испитале подразумеване свакодневне релационе реалности везано за изолацију и ограничено кретање, социјално дистанцирање, ношење маске, уздржано поздрављање и одржавање хигијене руку у борби против вируса COVID-19 у Нигерији.

5 Уздржано поздрављање у овде употребљеном значењу односи се на нове начине поздрављања у намери да се на минимум ограничи физички контакт (нарочито руковање и грљење).

6 У Нигерији и даље брзо расте број случајева заразе COVID-19, те је 18. јуна 2020. достигао 18.480. Постоји могућност даљег брзог повећања јер се многе државе отварају као што је планирано. 
У последњих стотину година забележено је неколико епидемија коронавируса. Велики грип из 1918-1920. године, одмах после Првог светског рата, који је однео више од 50 милиона живота, имао је највећи утицај од свих великих епидемија током 20. века (Lima \& Sobral, 2020). Између 2002. и 2014. забележени су случајеви птичјег грипа (H5N1), тешког акутног респираторног синдрома (SARS) и блискоисточног респираторног синдрома (MERS) (Otter, Donskey, Yezli et al, 2016). Вируси H5N1, SARS и MERS су брзо заустављени пре него што су достигли пандемијске размере. У Нигерији су забележени случајеви заразе вирусом H5N1 код живине, али није пријављен ниједан случај заразе код људи (Oluwayelu, Meseko, Ayinmode et al, 2020). У Нигерији није забележен ниједан случај заразе вирусима SARS и MERS. Mеђутим, ебола, такође крајње заразна болест, откривена је у Нигерији у јулу 2014. године. У Нигерији је било укупно 20 случајева заразе еболом и 8 смртних случајева (Ogoina 2016). Пре него што је стигла у Нигерију, ебола је харала у западноафричким земљама Сијера Леоне, Либерија и Гвинеја, где је однела преко 11.000 живота. Чим је у Нигерији пријављен нулти случај еболе, за Нигеријце је уведено обавезно мерење температуре на јавним местима, забрањено је руковање, а појачана је хигијена руку (Ogoina 2016). Исто тако, затворене су школе, али није било ограничења кретања нити изолације. Треба напоменути да је епидемија еболе међу Нигеријцима донекле повећала иницијалну свест о пандемији као реалности у 21. веку. Уведени протоколи за спречавање еболе доживели су неуспех недуго након што је објављено да у Нигерији више нема ове болести. Односи који су се појавили услед пандемије COVID-19 поново су подигли свест и пратећу праксу увођења мера за спречавање пандемије.

Центар за инфективне болести (The Infectious Diseases Centre, IDC-Lagos) имао је главну улогу у лечењу заражених и за заустављање еболе. Исти овај Центар примио је и прве људе заражене вирусом COVID-19 у Нигерији. Реч је о центру који представља модел за третирање вируса COVID-19 у Нигерији и који је одиграо водећу улогу у заустављању пандемије. За разлику од еболе, COVID-19 има већи утицај. Друштвена свест о вирусу COVID-19 и препоручени протоколи за његово спречавање су све више уграђени у друштвени миље и подразумеване свакодневне друштвене односе и стварност у Нигерији. То не значи да су се протоколи строго поштовали. Међутим, утицаји протокола против ширења COVID-19 уткани су у свакодневне радње и стратегије путем којих Нигеријци реагују на реалности пандемије COVID-19. Овај рад има 6 главних делова. Први део садржи увод. Други дискутује о епистемологији социологије свакодневног живота у објашњењу пандемијске реалности, док трећи износи методологију. Четврти део представља осврт на запажања о протоколима за спречавање вируса COVID-19 који се примењују у Нигерији, пети садржи дискусију о налазима, а шести доноси закључак.

\section{Социологија свакодневног живота у реалности пандемије}

Пандемија COVID-19 још једном је потврдила став да актери граде и обнављају своје друштвено биће кроз значења која конструишу на основу друштвених интеракција и стварности (Harvey 2016, Ciocănel, Lazăr, Munch, et al, 2018). Људска бића још од давнина доживљавају налете коронавируса. Тумачења везана за разне сојеве коронавируса варирају од благог до тешког облика у зависности од епидемије односно 
пандемије болести и искусатва која су доживели актери. Тумачења Великог грипа из 1918-1920. године, затим вируса H5N1, SARS, MERS и у најновије време COVID-19, обично су усмерена претежно на значења опасних и озбиљних болести које могу брзо да проузрокују морбидитет односно смртност великог броја људи. За разлику од Великог грипа који је изазвао огромну смртност на глобалном нивоу, научници и медицински стручњаци успели су да спрече ширење вируса H5N1, SARS и MERS пре него што су они достигли размере пандемије међу људима. Стога многи актери посматрају та три вируса - H5N1, SARS и MERS - као пуке потенцијалне опасности са ограниченим штетним дејством. Многи други актери у интеракцији ван истраживања и биомедицинске заједнице знају врло мало или не знају готово ништа о овим сојевима коронавируса, па им придају ограничено значење у својој стварности.

Пандемија COVID-19 достигла је фазу глобалне свести сличне оној током Великог грипа 1918-1920, али не и исти степен односно стопе морбидитета и смртности. Информационе и комуникационе технологије, медији и друштвене мреже бесумње су допринели брзом ширењу информација о вирусу COVID-19, чак и у сиромашним земљама, што директно утиче на њихово тумачење међу људима. ${ }^{7}$ Научне и медицинске заједнице преставиле су COVID-19 као нов вирус без познатих лекова и вакцина (Wang, Horby, Hayden \& Gao, 2020, Rothan \& Byrareddy, 2020). Глобална здравствена заједница, као и масовни и друштвени медији, непрекидно обавештавају о глобалним стопама морбидитета и смртности услед вируса COVID-19, док државне власти такође уводе протоколе спречавања које грађани, као друштвени актери у интеракцији, стално тумаче и поштују на основу тумачења тих протокола. Друштвени актери граде своје пандемијске реалности на тумачењима заснованим на статистици о вирусу COVID-19, протоколима које уводе националне владе и међународне организације (пре свега Светска здравствена организација), као и на основу медијских вести и друштвених медија. Владе. међународне организације, агенције за вести и друштвене мреже представљају чворове комуникације од којих актери добијају, размењују и релационо тумаче информације о вирусу COVID-19. Добијене и подељене информације саме по себи не производе деловање већ начин на који актери у интеракцији тумаче те информације утичу на правце деловања. Отуда друштвена димензија вируса COVID-19 превазилази научну и медицинску статистику, анализе и вести које се шире. Уместо тога, друштвена тумачења која дају актери у интеракцији утичу на контекстуални облик стварности везано за пандемију COVID-19.

Друштвена тумачења и уграђене релационе радње везано за пандемију COVID-19 и даље се развијају. Постоји, међутим, глобална свест о томе да је пандемија главни узрочник морбидитета и смртности. Доступне информације такође показују да пандемија може брзо да оптерети и негативно утиче на сектор здравства, здравствене раднике, опрему и лекове јер број заражених расте изнад подношљивог нивоа (Chatterjee, Chatterjee, Kumar \& Shankar, 2020, Emanuel, Persad, Upshur, Thome et al, 2020). Из ових разлога се у бројним земљама препоручују, уводе и примењују мере спречавања заразе у виду изолације, социјалног дистанцирања, ношења маске, уздржаног поздрављања

7 Велики број Нигеријаца има приступ информационим и комуникационим технологијама и друштвеним мрежама захваљујући доступности релативно јефтиних половних електронских уређаја увезених из Кине (Omobowale 2013a, 2013b, 2012) 
и одржавања хигијене руку. Ове протоколе спроводе макроструктуре на глобалном и националном нивоу. Друштвени актери такође тумаче и реагују на вирус COVID-19 и на протоколе његовог спречавања на микронивоима, на основу постојећих интеракција са друштвеним и физичким окружењем. Ово истраживање стога се руководи епистемологијом социологије свакодневног живота, првенствено да би објаснило подразумеване нијансе са уграђеним значењима за интерпретативно разумевање реалности у вези са пандемијом COVID-19 у Нигерији.

\section{Методологија}

Ово истраживање усвојило је рефлексивни метод сакупљања и тумачења опсервационих и секундарних података. Подаци за ову студију сакупљени су из медијских извора на интернету и из свакодневних запажања о протоколима спречавања COVID-19 у виду изолације, социјалног дистанцирања, ношења маске, уздржаног поздрављања и одржавања хигијене руку у Нигерији. Истраживање је обезбедило податке из доступних медијских извора (укључујући BBC, Aljazeera, Punch Newspaper, Guardian Newspaper, Business Day, Nigerian Tribune, Vanguard Newspaper и Radio Nigeria Ibadan) и посматраних, наизглед безазлених интеракција у јавном окружењу од марта до маја 2020. године, али без директног физичког контакта са људима као актерима због етике према којој се истраживање руководило током периода пандемије (Magnani \& Magnani, 2020, Chaudhuri, 2020, Van Bavel, Baicker, Boggio et al, 2020). Посматрање је спроведено у граду Ибадану јер су протоколи спречавања COVID-19 ограничили путовање у друге градове и државе.

\section{Протоколи спречавања COVID-19 и свакодневни односи}

\section{а) Изолација}

Савезна влада Нигерије је 30. марта 2020. затворила државе Лагос и Огун, као и територију главног града Абуџе у оквиру ране стратегије за заустављање ширења новог коронавируса у заједници ${ }^{89}$. Многе остале државе такође су увеле одређене облике ограниченог кретања или полицијски час, затвориле школе, пијаце, продавнице и канцеларије и забраниле јавне и верске скупове за више од 10-20 особа. Основно начело било је да се „не крећу вируси, већ да људи крећући се преносе вирусе!" Политика затварања смишљена је да би се успорило ширење пандемије COVID-19. Три територије које су прве затворене биле су епицентри случајева заразе COVID-19 у Нигерији. До 30. марта, када је проглашена изолација, у Нигерији је потврђен свега 131 случај заразе COVID-19 (видети Nigeria Centre for Disease Control, 2020b). Од 30. марта до прве седмице јуна забележен је раст потврђених случајева

8 У Лагосу, Абуџи односно Огуну било је 81, 25 односно 3 случаја када су 30. марта 2020. ове територије затворене. Број заражених порастао је на 5.663 (Лагос), 862 (Абуџа) и 329 (Огун) до 6. јуна 2020. године (Nigeria Centre for Disease Control, 2020c).

9 Савезна влада затворила је и државу Кано 27. априла, када је број случајева заразе COVID-19 нагло порастао на 70. Број заражених у држави Кано је достигао 985 до 6. јуна 2020. године (Nigeria Centre for Disease Control, 2020c). 
од чак $8200 \%$, те је број заражених премашио 11.000. Хипотетички гледано, може се претпоставити да би заражених било још више да није уведена изолација. Међутим, широке народне масе не реагују на претпоставке. Оне реагују на новонастале, постојеће и поновљене ситуације и на основу њих граде реалност. Преовлађујућа изграђена реалност јесте да је изолација утицала на средства за живот и преживљавање. Људи отворено изјављују да је „вирус глади изазван изолацијом знатно смртоноснији од коронавируса”. С обзиром на то да су изолација и полицијски час негативно утицали на економске активности, нарочито је погођен велики број људи који раде и зарађују за живот у оквиру неформалног сектора. У немогућности да приступе државној помоћи, они су изолацију доживели као казну и процес гладовања који би их могао одвести у смрт (Osinusi, 2020). Истовремено са губитком прихода нагло су скочиле и стопе криминала, нарочито у осетљивим окружењима (видети, на пример, Mbah, 14 April 2020, Lambo, 14 April 2020). Због тога је изолација протумачена као мера која је осетљивим слојевима ускратила приходе без којих они не могу да преживе, излажући их несигурности. Изолација је постала непопуларна мера коју је наметнула влада, а која је негативно утицала на благостање и безбедност. Широка јавност није тумачила изолацију и ограничено кретање као мере за спречавање вируса COVID-19 већ као „лоше и штетне мере” због тога што су угрозиле опстанак, а државна помоћ није била доступна већини људи чији је опстанак доведен у питање услед изолације.

\section{б) Социјално дистанцирање}

Социјално или физичко дистанцирање је једна од важних превентивних мера прописаних и неопходних за спречавање пандемије COVID-19 на глобалном нивоу (Abel \& McQueen, 2020). У Нигерији се истицање социјалног дистанцирања сматра значајним јер је влада и на савезном нивоу и на нивоу појединачних држава забранила друштвене и верске скупове који би могли да доведу до блиског контакта међу људима. Сви који су покушали да окупе велики број људи или да приреде забаве били су строго осуђени, а преступници су ухапшени. Све школе, цркве, џамије и центри за разне догађаје су затворени, а ограничено је кретање између држава. Ове кораке додатно је подржао Нигеријски центар за контролу болести (Nigerian Centre for Disease Control, NCDC) тако што је организацијама издао стандардне оперативне процедуре за социјално дистанцирање. Сходно томе, многе организације, нпр. банке, обележиле су растојање од три метра како би обезбедиле социјално дистанцирање у својим пословницама и на банкоматима. Иако делује да је социјално дистанцирање постигнуто у појединим корпоративним окружењима, системи трговачког простора и јавног превоза не поштују протоколе социјалног дистанцирања (Radio Nigeria Ibadan, 2020).

Постојећа природа друштвених и културних односа је таква да дозвољава блиске физичке интеракције у структурама економског и друштвеног простора. На пример, трговачки простор служи као главна тачка за разне појаве, на пример дошаптавање цене, дељење хране и пића, одржавање састанака трговинских удружења у затвореном простору, грљење и руковање као симбол пријатељства и уговарања цена. 
Трговачки простор Ибадана окупља велики број неформално запослених радника и становништву обезбеђује основне намирнице и остала средства. Трговачки простори обично су густо насељени и у њима је готово немогуће кретати се без блиског контакта (Agusi, Ijoma, Nnochin, Njoku-Achu et al, 2020, Radio Nigeria Ibadan, 2020, Omobowale, 2019). Ово је изражено у примеру Бодиџе, највеће пијаце прехрамбених производа у југозападној Нигерији, која заузима површину од 56,9 хектара и привлачи продавце и купце из читаве Нигерија, као и неколико земаља на обали Западне Африке (Omobowale, 2019, Omobowale \& Omobowale, 2019). Људима из Ибадана и околине пијаца Бодиџа, као и све остале велике пијаце у Нигерији, представља главни центар за зарађивање за живот и друштвени опстанак. Према друштвеној екологији и распореду, ова пијаца је густо попуњена и на њој увек влада велика гужва, те је веома тешко постићи социјално дистанцирање упркос тренутној ситуацији са вирусом COVID-19. Немогуће је навести тачан број продаваца на пијаци Бодиџа. Међутим, сасвим је извесна процена да свакога дана ову пијацу посети око 5.000 трговаца и између 15.000 и 20.000 купаца. Број посетилаца пијаце Бодиџа и даље је велики упркос пандемији COVID-19. Наиме, не постоји никаква пракса социјалног дистанцирања на пијаци. Она је увек пуна људи, товара робе и возила/ камиона који се боре за место и нико не поштује социјално дистанцирање, чак ни у најмањој мери, зато што то простор не дозвољава. Поједини трговци и купци носе заштитне маске, чиме подсвесно шаљу поруку о социјалном дистанцирању као упозорење другима да их намерно не додирују. За многе трговце је социјално дистанцирање немогуће због тога што је друштвена блискост уграђена у свакодневни живот и трансакције на пијаци. Укратко, друштвена блискост представља језгро ове пијаце. Исто тако, образац јавног превоза у Нигерији омогућава близак контакт упркос прописима о држању физичке дистанце, па многобројна возила, трицикли и мотоцикли и даље тешко могу да се придржавају ових прописа.

\section{ц) Заштитне маске}

Употреба заштитних маски је једна од мера безбедности коју препоручују здравствени стручњаци током пандемије COVID-19 (Feng, Shen, Xia et al, 2020, Liu \& Zhang, 2020). Маска треба да заштити појединца од ширења вируса односно заразе капљичним путем док људи разговарају, кашљу или кијају. Првобитно је Светска здравствена организација (C3O) препоручивала ношење маски само здравственим радницима и зараженима, али како је у последње време вирус почео експоненцијално да се шири, С3О је препоручила ношење маски свим људима на јавним местима (BBC News, 2020). Међутим, упркос наглашеним биомедицинским и клиничким сврхама заштитне маске, ово истраживање је приметило необавезну друштвено-економску димензију у односу на ношење маске. Примећено је да је производња маски постала извор зараде многим локалним кројачима и осталим обученим или полуобученим радницима (видети, на пример, Odoh, 2020). Ти кројачи и трговци праве маске од локалних тканина и у великим количинама. Платнене маске су алтернатива медицинским маскама које здравствени радници и хирурзи носе у болници, а лако су доступне људима који не могу да приуште или нађу медицинске маске. 
Платнене заштитне маске се купују и продају поред пута и на улазу у јавне институције где је забрањен улазак без маске. Овакве маске коштају свега $100-150$ (\$0,270,41). C3О (WHO, 2020) је описала стандаризовани облик платнених маски које се морају користити као замена за медицинске. Ове платнене маске морају да имају три слоја - спољашњи, унутрашњи и средњи. Спољашњи слој треба да је направљен од водоотпорног материјала; унутрашњи слој мора да упија воду, док средњи слој мора да садржи филтер. Већина импровизованих маски које се продају на улици не испуњава препоручени стандард СЗО. Истраживачи су купили неколико тих маски као узорак. Оне су имале само један слој платна. Стога те маске не могу да пруже предвиђену заштиту. Нестандардне маске могу да пруже само симболичан осећај заштите онима који их носе, те да међу њима и онима који спроводе закон створе утисак да се поштује обавеза ношења маске, као и да обезбеде извор зараде уличним произвођачима и продавцима.

\section{д) Уздржано поздрављање}

Поздрави се користе у свакодневним интеракцијама кроз комуникацију у циљу одржавања интерперсоналних односа (Wei, 2010). Од избијања пандемије COVID-19 променио се начин поздрављања, поставши уздржан у мери у којој је то изводљиво. С3О упозорава на руковање и грљење јер се сматра да се њима преноси коронавирус. Друштвени систем Нигерије карактеришу међуљудски односи који почивају на неформалним поздравима. Због тога су смишљени симболични и иновативни поздрави. Поред опште препорученог и популарног додиривања лактом и стопалом, из реалности пандемије COVID-19 проистекли су и неки симболични изрази у знак поздрава (Ekpu, 2020). Неки од њих на језику јоруба гласе: „Поздрав у периоду коронавируса” (Aku asiko koro yi o), „Како код вас стоје ствари са коронавирусом?” (Bawo ni koro yi lodo yin), „Како се борите у овом периоду коронавируса?” (Bawo le se n cope ninu koro yi). Различити облици поздрава настали услед коронавируса користе се за изражавање људских осећања, забринутости, тумачења и релационе реалности током пандемије COVID-19 која је довела до проблема у погледу опстанка великог броја људи. На пример, „Како се борите са коро(ном)?” истовремено је поздрав и питање које се односи на сналажење у овом тешком периоду. Осим тога, молитве везано за коронавирус (тзв. коро молитве) често се користе као облик поздрава у интеракцијским процесима током пандемије COVID-19. Те молитве се користе да подсете људе на њихову религију и уверења током пандемије COVID-19 и постале су свакодневни поздрав јер су људи повезани у својим свакодневним активностима. Често коришћене молитве су „Даће Бог, наша крв биће горка за коронавирус” (Lagbara Olorun, eje wa'o koro fun koro), „Коронавирус неће ући у наше куће/домаћинства” (koro o ni rapala wo ile/ede wa o) и „Нећемо добити коронавирус, у име Исусово” (A o ni rogun coro l'oruko Jesu). Кроз ове молитве људи стварају и оживљавају сопствена значења и начин разумевања коронавируса који се приказује као демон или зли дух (emi koro) и који се може победити само ратним молитвама (видети Omobowale \& Oyelade 2017, Oyelade \& Omobowale 2015). 


\section{е) Хигијена руку}

Хигијена руку се, између осталих мера, глобално препоручује као витална стратегија против преношења вируса COVID-19 са човека на човека. Ово подразумева често прање руку сапуном и водом, као и употребу средства за дезинфекцију на бази алкохола (видети Cavanagh \& Wambier, 2020). Постојећи извештаји указују на то да око 150 милиона Нигеријаца нема приступ објектима/уређајима за прање руку (Ewepu, 2020). Приметили смо, међутим, да се у великом броју случајева живот људи у Нигерији мења тако што су на јавним местима обезбеђени уређаји и средства за прање руку. Постала је уобичајена пракса да се код куће, на радном месту, у верским објектима, тржним центрима и на пијацама обезбеђују сапун и вода, па људи приликом уласка перу руке што је чешће могуће. Ово је довело до настанка нових занимања, сналажљивости и разних иновација. Најупадљивији међу њима јесте посао који подразумева претварање кофа и буради у справе за прање руку, у прихватљивој мери прилагођене употреби на јавним местима. Велики број појединаца на локалном нивоу производи и продаје течни сапун, мада то није законом регулисано. Осим производње и продаје ових артикала, неки појединци су смислили и посебан начин зараде тако што нуде средства за прање руку, нарочито сапун и воду, на кључним локацијама на јавним местима, у чему их јавност такође подржава. Услед повећане потребе за редовним одржавањем хигијене руку, цене течног сапуна и средства за дезинфекцију руку у званичној продаји порасле су између $100 \%$ и $1000 \%$ (видети Onwuzoo, 2020). То је условило и повећану производњу и продају средстава за дезинфекцију руку и сапуна без званичне робне марке. Ово је повећало зараду продавцима, а сапун и средства за дезинфекцију учинила приступачнијим, иако није отклоњена опасност повезана са употребом фалсификованих и нестандардних врста сапуна и средстава за дезинфекцију. Исто тако, шире се разне тврдње о домаћим лековима и личним мерама заштите. Међу њима је и тврдња да се џин из домаће производње (ogogoro, познати и као apeteshi) може користити као замена за средство за дезинфекцију руку. У ствари, појединци тврде и да треба пити ово домаће пиће како би се спречила или излечила зараза COVID-19. Стога се домаћи џин користи за прављење средства за дезинфекцију на бази алкохола, а неким људима је прешло у навику не само да њиме перу руке, него чак и да га пију у уверењу да он уништава коронавирус (видети Onwuzoo, 2020). И у Нигерији, баш као и на глобалном плану, хигијена руку је постала пракса услед страха или као лична заштита од заразе COVID-19 (видети Singhal, 2020). Неки људи перу руке само понекад, док други иду свуда са средством за дезинфекцију у џепу и користе га често, кад год се сете. На многим јавним местима где владају ограничења, међу којима су нпр. банке и тржни центри, стоје службеници задужени да посетиоцима скрећу пажњу на прање руку пре него што им дозволе да уђу у дати простор. Због тога су тумачења везано за COVID-19 претворила хигијену руку у свакодневну праксу и истовремено довела до ширења нерегулисане локалне производње и продаје течног сапуна и средстава за дезинфекцију руку упркос потенцијалним опасностима по здравље. 


\section{Даља расправа о налазима}

Осим биомедицинских и клиничких димензија пандемије COVID-19 у Нигерији, представљени резултати указују на очигледно субјективно схватање подразумеваних друштвено конструисаних контекста и нијанси уграђених у свакодневне интерпретације вируса COVID-19 јер су људи усмерени једни на друге у овом тешком периоду. Стога ово довољно говори о начину на који друштвени актери конструишу и реконструишу читав свој свет док националне владе, корпоративна тела и организације саветују локалне и глобалне мере за спречавање вируса COVID-19. Друштвена тумачења протокола везано за COVID-19, укључујући изолацију, социјално дистанцирање, ношење маске, уздржано поздрављање и одржавање хигијене руку, произлазе из свакодневне интеракције људи, те се путем таквих тумачења преносе контекстуална значења о ономе шта представљају дати протоколи.

Нема сумње да се реалност пандемије COVID-19 и протоколи за њено спречавање могу најбоље разумети на основу друштвених тумачења и значења друштвених актера. Друштвени актери су циљна публика, па су њихова субјективна тумачења и значења пресудна за разумевање реалности пандемије COVID-19 на властитом плану и у односу на друге, што је повезано са индивидуалним и друштвеним развојем (Olutayo, 2014). Током изолације, широм земље нестају пословне стратегије и стратегије преживљавања и патње постају неподношљиве, нарочито за неформално запослене раднике који живе од зараде на дневном нивоу. Стога политика изолације није протумачена у смислу заустављања заразе COVID-19, већ као начин ширења „вируса глади” у сиромашним слојевима народа. Ово подразумева да је већина људи доживела изолацију не као начин спречавања заразе COVID-19 већ као начин за експлоатацију сиромашних и њихово спуштање испод линије сиромаштва. Због тога успешно спровођење и поштовање политике изолације зависи од контекстуалних значења и друштвених тумачења која дају социјални актери.

У протоколе спречавања засноване на социјалном дистанцирању и уздржаном поздрављању такође су уткана осећања, перцепције и значења које друштвени актери конструишу приликом интеракције током пандемије (Adler, Adler \& Fontana, 1987). Док социјално дистанцирање обезбеђује физичку дистанцу између две особе које се сусретну током ове пандемије, друштвена тумачења социјалног дистанцирања преносе и нека друга значења социјалног дистанцирања, нарочито у трговачким односима. Пијаца је интеракцијски друштвени простор у којем се друштвени актери боре за зараду, па је социјално дистанцирање дословно немогуће. Друштвени простор у овом контексту обликују међуљудски односи и уређен је друштвеним и културолошким правилима уграђености (видети Omobowale, 2019; Omobowale \& Omobowale, 2019; Adebayo, Falase \& Akintunde, 2017; Zieleniec, 2007). Исто тако, уздржано поздрављање као облик свакодневних поздрава развио се као димензија емоционалне стратегије за конструктивну и интерпретативну борбу са друштвеним реалностима пандемије COVID-19. Интерпретативни контекст „короне” постао је домен у којем чланови друштва изражавају своја осећања, емоције, молитве, ставове и тумачења везано за пандемију COVID-19. Заштитне маске и хигијена руку такође су утицале на свакодневне интеракције и реалност. Обавеза ношења заштитне маске и одржавања хигијене руку коју је наметнула влада омогућила је начин преживљавања локалним произвођачима, али је овај нови сектор и даље нерегулисан, па, самим тим, стандарди нису загарантовани. 


\section{Закључак}

Нигерија је прогласила пандемију COVID-19 у фебруару 2020. године. Упркос уложеним напорима и одређеном степену припремљености, број заражених вирусом COVID-19 нагло је порастао на чак 18.000 до треће седмице јуна. Примарни фокус био је на мерама задржавања ширења коронавируса. Међутим, мере заустављања заразе као што су изолација, социјално дистанцирање, ношење маске, одржавање хигијене руку и уздржано поздрављање развиле су интерпретативне радње путем којих друштвени актери у интеракцији настављају да граде своје животе током пандемије. Изолација и социјално дистанцирање тумаче се као строге мере које отежавају опстанак, па су у великој мери одбачени, док су ношење маске и одржавање хигијене руку створили нов извор прихода и начин преживљавања за многобројне обучене и полуобучене људе који производе нестандардизоване заштитне маске и средства за одржавање хигијене руку и тако зарађују за живот. Иако у највећој могућој мери избегавају руковање и грљење, људи ипак непрекидно уводе нове поздраве са уграђеним значењима у нади да се неће заразити вирусом COVID-19. Тешко је потврдити да ли су мере спречавања заразе COVID-19 ефикасне, али су начини тумачења тих мера произвели контекстуалне реалности као одговор актера на пандемију.

\section{REFERENCES / ЛИТЕРATУРA:}

Abel, T and McQueen, D (2020). The COVID-19 calls for spatial distancing and social closeness: not for social distancing. Int J Public Health. https://doi.org/10.1007.s00038020-01366-7

Adebayo, K., Falase, O. S. and Akintunde, A. (2019). 'Here, we are all equal!': Soccer viewing centers and transformation of age social relations among fans in South-Western Nigeria. Soccer and Society, 20 (2), 360-376.

Adler, P. A., Adler, P., \& Fontana, A. (1987). Everyday life sociology. Annual Review of Sociology, 13(1), 217-235.

Agusi, E. R., Ijoma, S. I., Nnochin, C. S., Njoku-Achu, N. O., Nwosuh, C. I. and Meseko, C. A. (2020). The COVID-19 pandemic and social distancing in Nigeria: ignorance or defiance. The Pan African Medical Journal, 35(2):52. DOI: 10.11604/ pamj.2020.35.2.23649

$B B C$ News (2020, June 6). Coronavirus: WHO advises to wear masks in public areas. $B B C$ News. Retrieved from:https://www.bbc.com/news/health-52945210 on June 9, 2020.

Cavanagh, G; and Wambier, C. G. (2020). Rational hand hygiene during the Coronavirus (COVID-19) pandemic. JAAD Online, Volume 82, Issue 6, E221, June 01, 2020, DOI: https://doi.org/10.1016/j.jaad.2020.03.090

Chatterjee, K., Chatterjee, K., Kumar, A., \& Shankar, S. (2020). Healthcare impact of COVID-19 epidemic in India: A stochastic mathematical model. Medical Journal Armed Forces India, 76 (2), 147-155.https://doi.org/10.1016/j.mjafi.2020.03.022

Chaudhuri, T. (2020, April 26). Collecting data during COVID-19: How do we address data quality?. Retrieved from:/https://medium.com/@trishachaudhuri/collecting-data-during-covid-19-477de14bdd2 on June 9, 2020. 
Ciocănel, A., Lazăr, F., Munch, S., Harmon, C., Rentea, G. C., Gaba, D., \& Mihai, A. (2018). Helping, mediating, and gaining recognition: The everyday identity work of Romanian health social workers. Social Work in Health Care, 57(3), 206-219.

Ekpu, R. (2020, March 24) Covid-19: Why we must panic. Guardian Newspaper. Retrieved from: https://guardian.ng/opinion/covid-19-why-we-must-panic/ on May 30, 2020.

Emanuel, E. J., Persad, G., Upshur, R., Thome, B., et al. (2020). Fair allocation of scarce medical resources in the time of Covid-19. The New England Medical Journal 382:20492055 DOI: 10.1056/NEJMsb2005114.

Ewepu, G. (2020). COVID-19: 150m Nigerians lack access to hand-washing facilities - WaterAid. Retrieved from: https://www.vanguardngr.com/2020/03/covid-19-150m-nigerians-lack-access-to-hand-washing-facilities-wateraid on August 13, 2020.

Harvey, J. (2018). Theorising everyday life after acquired brain injury. Disability \& Society, 33(1), 78-93.

Lambo, D. (2020, April 14), Police arrest 130 hoodlums over Lagos attacks. Punch. Retrieved from: https://punchng.com/police-arrest-130-hoodlums-over-lagos-attacks/on April 14, 2020.

Lima M. L. and Sobral J. M. (2020). Threat and Oblivion: Interpreting the Silence Over the Spanish Flu (1918-19). In: Jodelet D., Vala J., Drozda-Senkowska E. (eds) Societies Under Threat. Frontiers in Sociology and Social Research, vol 3. Springer, Cham. https://doi.org/10.1007/978-3-030-39315-1_15

Magnani, N. and Magnani, M. (2020) Material methods for a rapid-response anthropology. Social Anthropology/Anthropologie Sociale 28 (2): 312-314 Special Section Article Accessed 12 June 2020 from/https://onlinelibrary.wiley.com/doi/epdf/10.1111/1469 8676.12813.

Mbah, F. (2020, April 14). Nigeria: Lagos residents defend homes against curfew bandits. Aljazeera. Retrieved from: https://www.aljazeera.com/news/2020/04/nigeria-lagos-residents-defend-homes-curfew-bandits-200414165917113 on April 16, 2020.

Nigeria Centre for Disease Control (2020a). COVID-19 Nigeria. Retrieved from: https:// covid19.ncdc.gov.ng/on June 4, 2020.

Nigeria Centre for Disease Control (2020b, March 30).COVID-19 Outbreak in Nigeria Situation Report S/N: 031. Retrieved from:/https://ncdc.gov.ng/diseases/sitreps/?cat $=14 \&$ name $=$ An\%20update $\% 20$ of $\% 20$ COVID-19\%20outbreak\%20in $\% 20$ Nigeria on June 6, 2020.

Nigeria Centre for Disease Control (2020c, June 6) COVID-19 NIGERIA 6 June 2020. Retrieved from: https://covid19.ncdc.gov.ng/report/ on June 6, 2020.

Odoh, I. (2020, April 20). Local manufacture of face masks takes off in race to contain coronavirus. Business Day. Retrieved from:https://businessday.ng/coronavirus/article/local-manufacture-of-face-masks-takes-off-in-race-to-contain-coronavirus/amp, on 6 June, 2020.

Ogoina, D. (2016). Behavioural and emotional responses to the 2014 Ebola outbreak in Nigeria: a narrative review. International Health, 8(1), 5-12.

Olutayo, A. O. (2014). 'Verstehen', Everyday Sociology and Development: Incorporating African Indigenous Knowledge. Critical Sociology, 40 (2), 229-238. 
Oluwayelu, D. O., Meseko, C. A., Ayinmode, A. B., Adebiyi, A. I., Lawani, M. A., \& Kakulu, F. O. (2020). Re-emergence of Highly Pathogenic Avian Influenza H5N1 in Nigeria, 2014-2016: Role of Social Network and Value Chain Forces in Interstate Transmission. Virologica Sinica. https://doi.org/10.1007/s12250-020-00201-w

Omobowale, A. O. (2012). Global E-Waste Management and Second-Hand Consumption in the Third World: Substandard Context and Tokunbo Phenomenon in Nigeria. The Nigerian Journal of Sociology and Anthropology, 10, 88-99.

Omobowale, A. O. (2013a). The Tokunbo Phenomenon and the Second-hand Economy in Nigeria. Oxford: Peter Lang Publishing.

Omobowale, A. O. (2013b). “Tokunbo ICT: Symbolic-Rationality of Second-Hand ICT Utilization in Nigeria” International Journal of Sociology and Social Policy, 33 (7/8), 509-523.

Omobowale, A. O. and O. K Oyelade (2017). Spiritual Embodiment in Yoruba Pentecostalism in Southwestern Nigeria. In M. Wilkinson and P. Althouse (eds.) Pentecostals and the Body: Annual Review of Sociology of Religion, 8, Leiden: Brill NV, 196-213.

Omobowale, M. O and Omobowale, A.O. (2019). Oju and Inu: Solidarity in the Informal Market Space in Ibadan, Nigeria. Journal of Black Studies. 50(4), 401-420.

Omobowale, M. O. (2019). Class, Gender, Sexuality and Leadership in Bodija Market, Ibadan, Nigeria. Journal of Anthropological Research. 75 (2), 235-251. Onwuzoo, A. (2020, May 17). Using 'ogogoro' as hand sanitizer ineffective against COVID-19Experts. Punch. Retrieved from: from https://healthwise.punchng.com/using-ogogoro-as-hand-sanitiser-ineffective-against- covid-19-experts/ on June 1, 2020.

Osinusi, F. (2020, April 23). Lockdown Of Lagos Is Already Breeding Hunger Virus, Youths Are Becoming Restless, Says Bode George. Nigerian Tribune. Retrieved from: https:// tribuneonlineng.com/lockdown-of-lagos-is-already-breeding-hunger-virus-youthsare-becoming-restless-says-bode-georgel on April 24, 2020.

Otter, J. A., Donskey, C., Yezli, S., Douthwaite, S., Goldenberg, S. D. \& Weber, D. J. (2016). Transmission of SARS and MERS coronaviruses and influenza virus in healthcare settings: the possible role of dry surface contamination. Journal of Hospital Infection, 92(3), 235-250.

Oyelade, O. K. and Omobowale, A. O. (2015). Ethnography of Pentecostal Warfare Prayer among the Yoruba of South-west Nigeria. Orita: Ibadan Journal of Religious Studies 47 (1\&2), 197-211.

Radio Nigeria Ibadan (2020, May 4) Low Compliance Recorded By COVID-19 Task Force In Ibadan Markets. Radio Nigeria Ibadan. Retrieved from:/https://radionigeriaibadan. gov.ng/2020/05/04/low-compliance-recorded-by-covid-19-task-force-in-ibadan-markets/ on August 13, 2020.

Rothan, H. A., and Byrareddy, S. N. (2020). The epidemiology and pathogenesis of coronavirus disease (COVID-19) outbreak. Journal of Autoimmunity, https:/doi org/10.1016/j.jaut.2020.102433.

Singhal, T. (2020). A Review of Coronavirus Disease-2019 (COVID-19) The Indian Journal of Pediatrics 87,281-286.

Van Bavel, J. J., Baicker, K., Boggio, P. S., Capraro, et al (2020). Using social and behavioural science to support COVID-19 pandemic response. Nature Human Behaviour, 4, 460471.https://doi.org/10.1038/s41562-020-0884-z 
Wang, C., Horby, P. W., Hayden, F. G., \& Gao, G. F. (2020). A novel coronavirus outbreak of global health concern. The Lancet, 395(10223), 470-473.

Wei, L. (2010). The Functions and Use of Greetings. Canadian Social Science 6(4), 56-62.

World Health Organisation (2020). Coronavirus disease (COVID-19) advice for the public: When and how to use masks. Retrieved from: https://www.who.int/emergencies/ diseases/novel-coronavirus-2019/advice-for-public/when-and-how-to-use-masks on 6 June, 2020.

Zieleniec, A. (2007). Space and Social Theory. London: Sage. 